\title{
TWO NEW SPECIES OF BEILSCHMIEDIA (LAURACEAE) FROM BORNEO
}

\author{
SACHIKO NISHIDA \\ The Nagoya University Museum, Furo-cho, Chikusa-ku, Nagoya 464-8601, Japan \\ e-mail: nishida@num.nagoya-u.ac.jp
}

\begin{abstract}
SUMMARY
Two new species of Beilschmiedia Nees (Lauraceae) from Borneo, B. crassa and B. microcarpa, are described and illustrated. Beilschmiedia crassa is distinguished from the other Bornean Beilschmiedia species by its thick and strongly coriaceous, narrowly ovate leaves and flowers with a thick receptacle. Beilschmiedia microcarpa is distinct in the combination of the following characters: its glabrous narrow buds, opposite, elliptic, chartaceous leaves with raised veins on the upper surface, flowers with short filaments, and relatively small fruits.
\end{abstract}

Key words: Beilschmiedia, Lauraceae, Borneo, new species.

\section{INTRODUCTION}

Beilschmiedia Nees is one of the larger genera of Lauraceae (Nishida, 2001) and includes about 250 species distributed mainly in the paleotropics (Van der Werff, 2001). It is usually distinguished from the other Lauraceae genera by its paniculate or racemose inflorescences not strictly cymose at the terminal division, bisexual and trimerous flowers with six equal to subequal tepals, six to nine fertile stamens with 2-celled anthers, and fruits lacking cupules (Nishida, 1999).

Revisional studies have been made for the genus in several regions: in China and Indochina (Liou, 1934), Taiwan (Liao, 1995), Congo and tropical Africa (Robyns \& Wilczek, 1949), Cameroon (Fouilloy, 1974), Madagascar (Van der Werff, 2003), the neotropics (Kostermans, 1938; Nishida, 1999), New Zealand (Wright, 1984) and Australia (Hyland, 1989). However, the genus has still to be revised for the Flora Malesiana region, except for the fact that Kochummen (1989) treated the genus for the Tree Flora of Peninsular Malaysia. Since this region is apparently one of the centres of species diversity for this genus, taxonomic revision of the genus in the region has been awaited.

The author intends to revise the genus Beilschmiedia in the Flora Malesiana region, and is now focusing on the Bornean species. Twenty-eight species (and one variety) were recognized for the genus on the specimen labels from Borneo (Nishida, 2001), but after careful study of specimens including types, only 22 species were confirmed to occur on the island. Besides them, three species were found as new after publishing the checklist (Nishida, 2001). One of them was published recently (Nishida, 2005) and the last two are presented here. 


\section{MATERIAL AND METHODS}

Specimens used for the descriptions and illustrations were loaned from K, KEP, L, SAN and SAR. To compare these specimens, specimens from A, BO and UC were also examined. All dimensions given are for dried materials except for the floral characters. Flowers were soaked in boiling water before observation and measurement.

\section{DESCRIPTION OF TAXA}

\section{Beilschmiedia crassa Sach. Nishida, spec. nov. - Fig. 1}

A congeneris borneensibus, receptaculo crasso, et foliis crassis anguste ovatisque differt. - Typus: Nooteboom 1661 (holo L; iso SAR), Malaysia, Borneo, Sarawak, Kalabit Highlands, Bario, alt. c. 1000 m, fl., 25 March 1970.

Tree to $20 \mathrm{~m}$ tall. Bark brown to reddish brown, smooth. All parts, except for terminal buds and inflorescences, glabrous. Twigs terete, slightly compressed when young, 3-5 mm diam., light to dark brown; buds ovoid, reddish brown, sparsely pubescent with short and curly or dusty hairs. Leaves alternate or subopposite, evenly arranged; blade thick, strongly coriaceous, narrowly ovate, $13-23$ by $3-9.5 \mathrm{~cm}$, base obtuse, margin flat, apex acute, both surfaces drying ochre, upper surface slightly glossy, lower surface matt, unknown whether glaucous or not, midrib impressed or slightly raised above, raised below, secondary veins 7-10 pairs, raised on both sides, tertiaries not percurrent, minor venation coarse, conspicuously raised on both sides, minor veins thick; petioles $1.3-1.7 \mathrm{~cm}$ long, flat to canaliculate above, drying almost black. Inflorescences axillary, paniculate, 4-6 cm long, sparsely pubescent, each bearing 20-30 flowers; pedicels c. $1 \mathrm{~mm}$ long. Flowers red, c. $3 \mathrm{~mm}$ long, c. $2 \mathrm{~mm}$ diam. at anthesis. Tepals 6, almost equal, c. 1 by $0.8 \mathrm{~mm}$, pubescent on both sides. Stamens $6-9$, c. $0.8 \mathrm{~mm}$ long, all filaments shorter than anthers, pubescent; anthers glabrous, obtuse to truncate at apex. Staminodes 3 (when stamens are 9) to 6 (when stamens are 6); staminode (3 or less) in third whorl narrowly sagittate, c. $0.9 \mathrm{~mm}$ long, with a pair of glands; 3 staminodes in fourth whorl subulate, c. $0.7 \mathrm{~mm}$ long. Pistil c. $1.4 \mathrm{~mm}$ long; ovary ovoid, sparsely pubescent, c. $1 \mathrm{~mm}$ long; style terete, glabrous, c. $0.4 \mathrm{~mm}$ long. Receptacle c. $1 \mathrm{~mm}$ thick. Infructescences 6-7 cm long; pedicels c. $5 \mathrm{~mm}$ diam., not apically constricted. Fruits spherical, c. 3 by $3.3 \mathrm{~cm}$, drying brown, surface warty.

Distribution - Endemic to Borneo, known only from Bario and Kapit in Sarawak.

Habitat \& Ecology - In mossy montane forests on sandstone. Altitude 880-1000 m. Flowering: March; fruiting: August.

Notes - This species is distinct firstly in its flowers with a thick (c. $1 \mathrm{~mm}$ ) receptacle. It is very rare for Beilschmiedia to have flowers with a thick receptacle; at least there is no other species with such a character in Borneo, Peninsular Malaysia, Sumatra or Java. In vegetative characters, $B$. crass $a$ is distinct in the thick and strongly coriaceous, narrowly ovate leaves from the other Bornean Beilschmiedia species.

Beilschmiedia crassa also differs from most of the other Bornean Beilschmiedia species in the flowers with often less than 9 fertile stamens. Flowers of Beilschmiedia have usually 6 or 9 fertile stamens representing the first to third whorls, and in the case with only 6 fertile stamens 3 stamens in the third whorl are sterile. Flowers of B. crassa have 6-9 fertile stamens (usually less than 9), because stamens in the third whorl are 


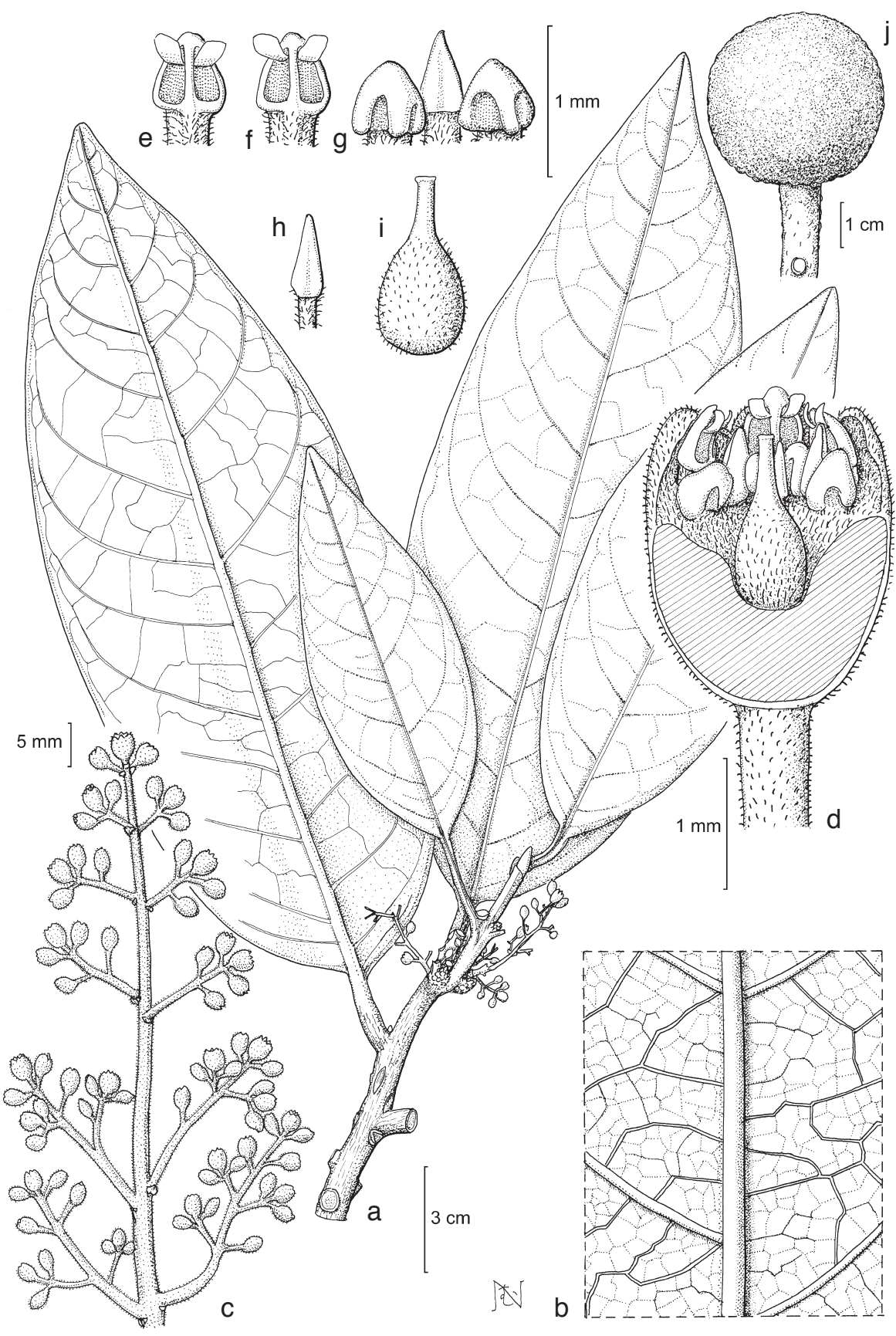

Fig. 1. Beilschmiedia crassa Sach. Nishida. a. Habit; b. venation pattern (abaxial view); c. inflorescence; d. flower (front part removed); e. first whorl stamen (adaxial view); f. second whorl stamen (adaxial view); g. third whorl staminode (abaxial view); h. fourth whorl staminode (abaxial view); i. pistil; j. fruit (a, b, d-i: Nooteboom 1661; c: reconstructed from Nooteboom 1661; j: S 36124). 
often sterile. Since the flowers do not appear abnormal, this floral feature seems to be a character of this species. Variation in the number of stamens is also seen in the other Beilschmiedia species. Beilschmiedia tooram (Bailey) B. Hyland from Australia sometimes has flowers with 4 or 5 stamens, although there are 6 stamens in a perfect flower (Hyland, 1989). Beilschmiedia hexanthera van der Werff from French Guiana is characterized with 6 fertile stamens representing the first and second whorls, but the author recognized a few flowers with 7 stamens (because of one fertile stamen in the third whorl) even in the type collection.

Additional specimens examined:

MALAYSIA. Sarawak: S 36124 (SAR), S 36333 (L, SAR).

\section{Beilschmiedia microcarpa Sach. Nishida, spec. nov. - Fig. 2}

Haec species Beilschmiediae glauciphyllae affinis, sed a qua foliis chartaceis, floribus minoribus, fructibus ellipsoideis et minoribus differt. - Typus: SAN 82219 (Krispinus) (holo L; iso K, KEP, SAN, SAR), Malaysia, Sabah, Tawau, NBT camp, Luasong, fl., 14 March 1977.

Tree to $9 \mathrm{~m}$ tall. Bark greyish to reddish brown, smooth. All parts, except for the flowers, almost glabrous. Twigs terete, c. $2 \mathrm{~mm}$ diam., greenish brown to dark brown; buds narrowly ovoid (c. $2 \mathrm{~mm}$ diam.), blackish. Leaves opposite, evenly arranged, blade chartaceous, matt or slightly glossy, elliptic, $11-19$ by $5-8 \mathrm{~cm}$, base cuneate to obtuse, margin flat, apex acuminate, lower surface green, midrib impressed or slightly raised above, raised below, secondary veins 7-9 pairs, slightly raised above, raised below, tertiary veins not percurrent, minor venation relatively coarse, slightly raised on both sides; petioles $0.7-1.5 \mathrm{~cm}$ long, flat above, drying brown. Inflorescences axillary or crowded around a node of new twigs, paniculate, 8-12 cm long, each bearing c. 20 flowers; pedicels 2-5 mm long. Flowers greenish or whitish yellow, c. $2 \mathrm{~mm}$ long, c. $2 \mathrm{~mm}$ diam. at anthesis. Tepals 6 , equal, ovate, c. 1.7 by $1 \mathrm{~mm}$, sparsely pubescent inside and along edges. Stamens 9 , in first and second whorls c. $0.9 \mathrm{~mm}$ long, in third whorl c. $1.2 \mathrm{~mm}$ long, all filaments shorter than anthers, pubescent; anthers glabrous, acute at apex. Staminodes 3, sagittate, c. $0.6 \mathrm{~mm}$ long. Pistil glabrous; ovary ovoid, c. $0.5 \mathrm{~mm}$ long; style terete, c. $0.7 \mathrm{~mm}$ long. Infructescences $5-8 \mathrm{~cm}$ long; pedicels 1.5-3 mm diam., constricted at apex when young, but not constricted when mature. Fruits ellipsoid, c. 3.5 by $1.6 \mathrm{~cm}$, drying brown, surface smooth.

Distribution - Endemic to Borneo, known from N Borneo (Miri, northern tip of Sarawak, and Sabah) and E Kalimantan (Kutei).

Habitat \& Ecology - Primary forests on hills; on loam soils containing limestone, sandy or clay soils. Altitude up to $1300 \mathrm{~m}$. Flowering: late January, March; fruiting: October, February.

Notes - There are ten opposite-leaved species of Beilschmiedia in Borneo, but among them only B. glauciphylla Kosterm. and this new species share a combination of the following characters: narrow glabrous terminal buds, elliptic leaves and short filaments. The most discriminating character between the two species is in the fruits: fruits of B. glauciphylla are club- or spindle-shaped and large (up to $12 \mathrm{~cm} \mathrm{long),} \mathrm{while}$ the fruits of $B$. microcarpa are ellipsoid and relatively small (up to c. $3.5 \mathrm{~cm}$ long). Flower size is also different: usually c. $4 \mathrm{~mm}$ diam. in B. glauciphylla and c. $2 \mathrm{~mm}$ diam. 


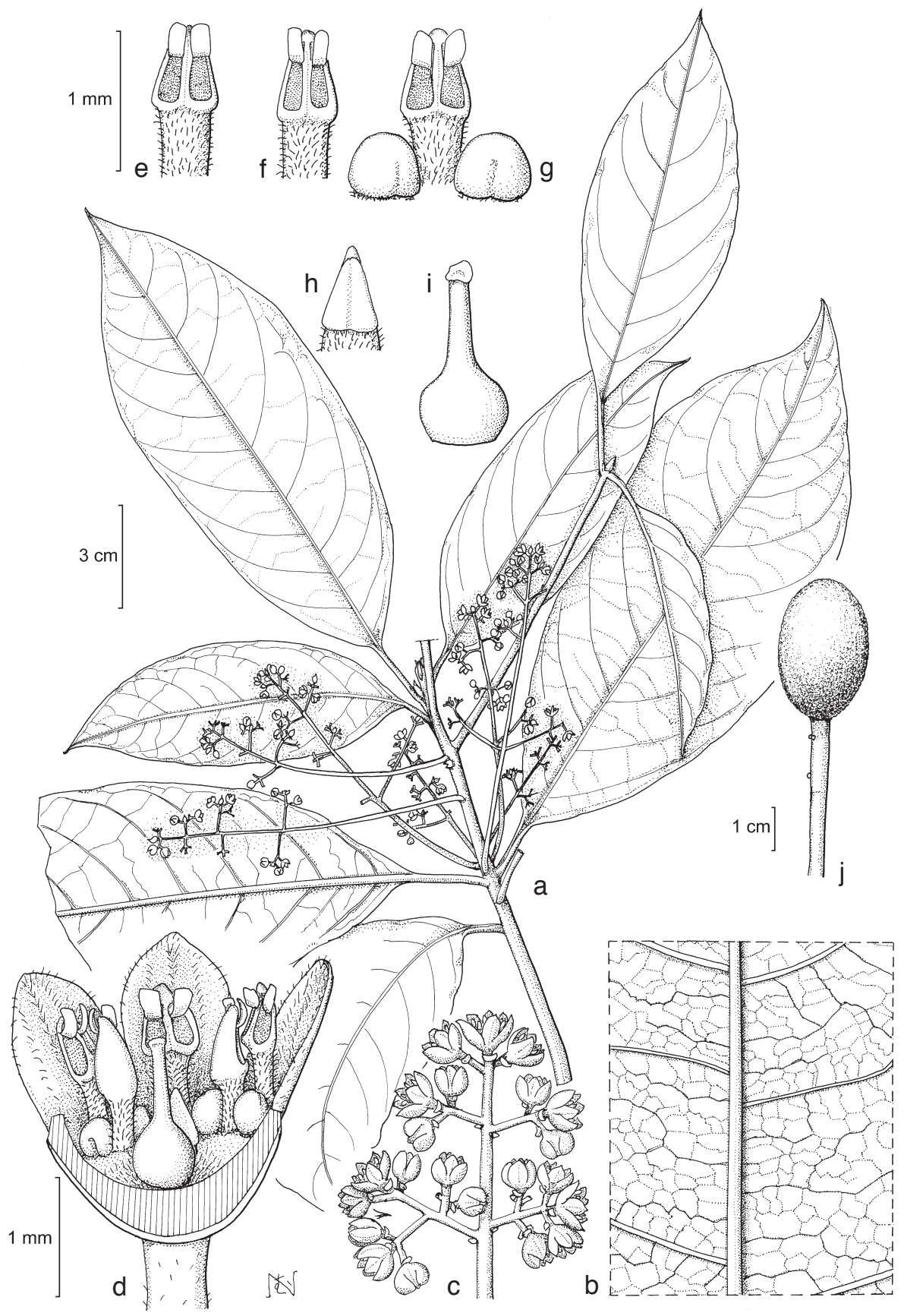

Fig. 2. Beilschmiedia microcarpa Sach. Nishida. a. Habit; b. venation pattern (abaxial view); c. inflorescence; d. flower (front part removed); e. first whorl stamen (adaxial view); f. second whorl stamen (adaxial view); g. third whorl staminode (abaxial view); h. fourth whorl staminode (abaxial view); i. pistil; j. fruit (a, b, d-i: SAN 82219; c: reconstructed from SAN 82219; j: SAN 65307). 
in $B$. microcarpa. Vegetatively, they can be usually distinguished by the leaf texture: B. glauciphylla has coriaceous leaves and B. microcarpa has chartaceous leaves, although the leaf texture may have some variation under different conditions. Beilschmiedia glauciphylla is distributed in the central part of Sarawak, while B. microcarpa is found in the northern part of Sarawak, Sabah and the eastern part of Kalimantan.

This new species was named with the epithet 'microcarpa'. This is because this species has smaller fruits than B. glauciphylla, a species most closely approaching the new species. In fact the fruits of $B$. microcarpa are not so conspicuously small compared to the other species of this genus.

Additional specimens examined:

MALAYSIA. Sarawak: S 38033 (KEP, L). — Sabah: SAN 33320 (K, SAR), SAN 65307 (L, SAN), SAN 136935 (SAN).

INDONESIA. East Kalimantan: Kostermans 21418 (L, SAR).

\section{ACKNOWLEDGEMENTS}

The author is grateful to the herbaria A, BO, K, KEP, L, SAN, SAR and UC for allowing her to study their specimens. The author also thanks Hidetoshi Nagamasu for improving the manuscript and Latin diagnoses, and Mutsuko Nakajima for preparing the excellent illustrations. This study was partly supported by grants from the Ministry of Education, Science and Culture, Japan (\#09NP1501 and 10041169).

\section{REFERENCES}

Fouilloy, R. 1974. Lauraceae. Flore du Cameroun 18: 3-87.

Hyland, B.P.M. 1989. A revision of the Lauraceae in Australia (excluding Cassytha). Austral. Syst. Bot. 2: $135-367$.

Kochummen, K.M. 1989. Lauraceae. In: F.S.P. Ng (ed.), Tree Flora of Malaya, vol. 4: 98-178. Longman, Malaysia.

Kostermans, A.J.G.H. 1938. Revision of the Lauraceae V, a monograph of the genera: Anaueria, Beilschmiedia (American species) and Aniba. Recueil Trav. Bot. Neerl. 35: 834-928.

Liao, J.C. 1995. The taxonomic revisions of the family Lauraceae in Taiwan (2nd ed.). National Taiwan University, Taipei.

Liou, H. 1934. Lauracées de Chine et d'Indochine. Hermann \& Cie, Paris.

Nishida, S. 1999. Revision of Beilschmiedia (Lauraceae) in the neotropics. Ann. Missouri Bot. Gard. 86: 657-701.

Nishida, S. 2001. Notes on Beilschmiedia (Lauraceae) of Southeast Asia 1: checklist of the Bornean species with the description of a new species. Acta Phytotax. Geobot. 52: 103-113.

Nishida, S. 2005. A new species of Beilschmiedia (Lauraceae) from Borneo. Novon 15: 343-345.

Robyns, W. \& R. Wilczek. 1949. Contribution à l'étude des Lauracées du Congo Belge et de l'Afrique Tropicale. Bull. Jard. Bot. État 19: 457-507.

Van der Werff, H. 2001. An annotated key to the genera of Lauraceae in the Flora Malesiana region. Blumea 46: 125-140.

Van der Werff, H. 2003. A synopsis of the genus Beilschmiedia (Lauraceae) in Madagascar. Adansonia 25: 77-92.

Wright, A.E. 1984. Beilschmiedia Nees (Lauraceae) in New Zealand. New Zealand J. Bot. 22: 109-125. 